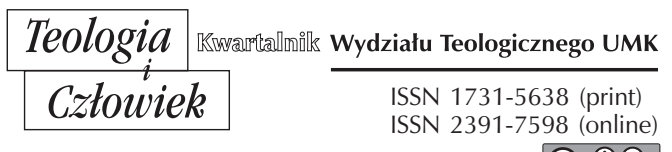

56(2021)4, ss. $45-60$

KS. TOMASZ DUTKIEWICZ

UNIWERSYTET MIKOŁAJA KOPERNIKA W TORUNIU

TD110CT@UMK.PL

ORCID 0000-0002-4004-2817

KS. DANIEL BRZEZINSSKI

UNIWERSYTET MIKOŁAJA KOPERNIKA W TORUNIU

DANBR@UMK.PL

ORCID 0000-0003-4680-3055

\title{
FILOZOFICZNA NAUKA O ZNAKACH JAKO POŚREDNIKACH LUDZKIEGO POZNANIA A ZNAKOWY CHARAKTER LITURGII
}

DOI: http://dx.doi.org/10.12775/TiCz.2021.026

Streszczenie. Filozoficzna refleksja prowadzona w ramach nauki o znakach ukazuje je jako pośredniki umożliwiające poznanie czegoś innego aniżeli one same. Wyraża to klasyczne, łacińskie określenie aliquid stat pro aliquo, w myśl którego „coś stoi zamiast czegoś innego”. Szczególnym narzędziem, w którym wykorzystane zostają znaki, służącym międzyosobowej komunikacji, jest ludzki język. Konieczność posługiwania się znakami w jej procesie zdeterminowana jest faktem, że wszelkie ludzkie poznanie bierze swój początek od zmysłów. Pociąga to za sobą konieczność sięgania po materialne pośredniki także tam, gdzie w grę wchodzi przekazywanie treści najbardziej nawet duchowych i wzniosłych. Również Bóg, komunikując się z człowiekiem, pozostaje niejako „skazany” na posługiwanie się znakami podpadającymi pod ludzkie zmysły.

Znakowy charakter posiada również święta liturgia, zarówno w swoim wymiarze anabatycznym, jak i w wymiarze katabatycznym. Znakowy charakter posiadają także wszelkie nabożeństwa i pobożność ludowa, w których dominuje - co oczywiste - wymiar anabatyczny, czyli kult oddawany Bogu przez człowieka. Wśród używanych w liturgii znaków szczególną rolę pełnią wyrażenia składające się na język, który - we właściwy so- 
bie sposób - wydaje się spełniać najbardziej charakterystyczne funkcje, na jakie wskazuje filozoficzna refleksja nad językiem, prowadzona w ramach semiotyki.

Słowa kluczowe: znak, liturgia, kult.

Abstract. The Philosophical Science of Signs as Intermediaries of Human Understanding versus the Sign-Based Character of the Liturgy. The philosophical reflection undertaken within the field of semiotics reveals signs as intermediaries that enable the knowledge of something other than themselves. This is expressed by the classic Latin phrase aliquid stat pro aliquo, which means that "something stands for something else." The human language is a unique tool that uses signs for interpersonal communication. The need to use signs in the process of communication is determined by the fact that all human knowledge begins with the senses. This entails the requirement to also make use of material intermediaries in cases where even the most spiritual and lofty ideas need to be conveyed. This is also true of God, who - when communicating with man - is in a way "limited" to using signs which are capable of being captured by the human senses.

The holy liturgy also has a sign-based character both in its anabatic dimension and in its katabatic dimension. The same holds true for all types of devotions and folk piety in which the anabatic dimension - that is worship being given by man to God - obviously has a predominant role. Among the signs used in the liturgy, a particular role is played by the expressions that make up the language, which - in its unique manner - appears to fulfill the most characteristic functions indicated by the philosophical reflection on language that takes place within semiotics.

Keywords: sign, liturgy, worship.

\section{WSTĘP}

Widziany w perspektywie historycznej człowiek jawi się - między innymi - jako istota od czasów najdawniejszych posługująca się znakami, które tworzy oraz wykorzystuje w procesach intersubiektywnej komunikacji. Fakt ten antropologia filozoficzna wyjaśnia, wskazując na specyficzny charakter ludzkiej natury, w której obok pierwiastka duchowego występuje - tworząc wraz z nim niepowtarzalne ludzkie compositum również pierwiastek materialny ${ }^{1}$. O ile dzięki pierwszemu z nich człowiek

${ }^{1} \mathrm{~W}$ niniejszym opracowaniu odwołujemy się do antropologii nawiązującej do realistycznej metafizyki, która - w myśl wskazań zawartych w poświęconych filozofii encyklikach Aeterni Patris Leona XIII i Fides et ratio Jana Pawła II - stanowić może właściwą filozoficzną podstawę uprawiania teologii. 
posiada zdolność myślenia abstrakcyjnego i tworzenia niematerialnych pojęć, o tyle drugi z wymienionych pierwiastków sprawia, że wszelkie ludzkie poznanie bierze swój początek od zmysłów, w międzyludzkiej zaś komunikacji czyni koniecznym przypisanie istniejącym w intelekcie niematerialnym ideom ich materialnych odpowiedników, zwanych właśnie znakami. Co więcej, nawet sam Stwórca - na co zwraca uwagę refleksja prowadzona w ramach filozofii Boga oraz filozofii religii - pozostaje w pewnym sensie zdeterminowany naturą swojego stworzenia, objawiając się człowiekowi w zmysłowych, znakowych osłonach.

Znakowy charakter posiada także święta liturgia (rozumiana jako zbawcze działanie in mysterio Chrystusa Głowy i całego Kościoła), zarówno w swoim wymiarze anabatycznym, jak i w wymiarze katabatycznym. Znakowy charakter posiadają również nabożeństwa i ludzka pobożność oraz ludzka modlitwa, w których dominuje - co oczywiste - wymiar anabatyczny, czyli kult oddawany Bogu przez człowieka, i poprzez które człowiek pragnie wyrazić swoje uznanie Boga jako najwyższej wartości oraz budzić w sobie oraz w innych osobach szacunek, jaki winien wobec Niego żywić ${ }^{2}$.

Fakt ten sprawia, że związki zachodzące pomiędzy refleksją filozoficzną, podejmującą zagadnienie natury znaków oraz funkcji, jakie pełnią one w procesach ludzkiego poznania i komunikacji, a refleksją teologiczną dotyczącą liturgii, okazują się być znacznie głębsze, aniżeli pozornie mogłoby się wydawać.

\section{CZłOWIEK JAKO TWÓRCA I UŻYTKOWNIK ZNAKÓW}

\subsection{ZNAK, CZYLI „COŚ, CO STOI ZAMIAST CZEGOŚ INNEGO"}

Za znak, w szerokim rozumieniu tego terminu, uznać możemy wszelki przedmiot, który stanowi środek poznania czegoś innego aniżeli on sam, odsyłając do czegoś poza sobą, co wydaje się w sposób trafny i zwięzły zarazem wyrażać - przywoływane w semiotyce - łacińskie określenie znaku: aliquid stat pro aliquo, w myśl którego „coś stoi zamiast

2 Zob. Z. Zdybicka, Człowiek i religia, Lublin 1993, s. 198. 
czegoś innego"3. Choć poszczególne znaki mogą przybierać różne formy, np. ikoniczne, motoryczne czy akustyczne, to zawsze posiadać one będą charakter materialny. Filozoficzna nauka o znakach wyróżnia w każdym ze znaków dwie warstwy: nosiciela znaczenia, którym jest podpadający pod ludzkie zmysły, intersubiektywnie dostępny przedmiot; oraz samo jego znaczenie. Występujący w funkcji znaku przedmiot pozostaje wzięty nie w swojej indywidualności, ale w typowej dla siebie postaci (kształcie, kolorze, brzmieniu itp.) Powiązanie występującego w funkcji znaku przedmiotu z jego znaczeniem zachodzi natomiast na mocy intencji twórcy znaku lub świadomości jego użytkownika ${ }^{4}$.

\subsection{POSŁUGIWANIE SIĘ ZNAKAMI JAKO POCHODNA LUDZKIEJ ROZUMNOŚCl}

Chociaż sam termin „semiotyka” (od gr. semeion - „znak”, „ślad”, „symptom”), znany już w starożytnej medycynie, stanowił pierwotnie określenie nauki o znamionach, czy też znakach chorobowych, których systematyczne ujęcie pozwalało trafnie rozpoznawać poszczególne choroby ${ }^{5}$, to jednak współcześnie zazwyczaj odróżnia się znak od symptomu, oznaki czy też objawu. Podczas gdy te ostatnie powstają bowiem niezależnie od ludzkich dobrowolnych działań, najczęściej na skutek pewnej zachodzącej relacji przyczynowo-skutkowej (np. dym jest oznaką palącego się ognia, wysypka albo gorączka symptomem czy też objawem choroby itp.), to użycie znaku posiada zawsze charakter świadomej ludzkiej czynności ${ }^{6}$.

3 Termin „semiotyka” na określenie filozoficznej dyscypliny o znakach językowych wprowadzili J. Locke i B. Bolano, upowszechnił zaś termin ten Ch. Peirce; zob. S. Kamiński, Metoda i język, Lublin 1994, s. 9.

4 Zob. A.B. Stępień, J. Herbut, Znak, w: J. Herbut (red.), Leksykon filozofii klasycznej, Lublin 1997, s. 562-563.

5 Por. A. Lekka-Kowalik, Semiotyka, w: A. Maryniarczyk (red.), Powszechna Encyklopedia Filozofii, t. 9, Lublin 2008, s. 19.

6 Tego typu rozumienie znaku nie jest, rzecz jasna, podzielane powszechnie, wszystko zależy tutaj od sposobu, w jaki definiuje się pojęcia. C.S. Peirce, wprowadzając rozróżnienie pomiędzy pojęciami „znaku” i „symbolu”, pierwszemu przypisuje pochodzenie naturalne, utożsamiając znak z objawem, czy nawet śladem, drugiemu natomiast pochodzenie sztuczne, będące wynikiem czystej konwencji; zob. S. Blackburn, Oksfordzki 
W szczególny sposób związek zachodzący pomiędzy faktem posługiwania się znakami a ludzką rozumnością uwyraźnia się w przypadku specyficznie ludzkiego narzędzia, jakim jest ludzki język. Już samo jego istnienie pozwala bowiem stwierdzić fakt posiadania przez człowieka zdolności poznania abstrakcyjnego. Składające się na język słowa (nazwy) nie są przecież niczym innym jak materialnymi (czy to $\mathrm{w}$ formie graficznej, w przypadku języka pisanego, czy też akustycznej, w przypadku języka mówionego) zamiennikami niematerialnych, istniejących w ludzkim intelekcie pojęć. Te zaś powstają $\mathrm{w}$ wyniku procesu poznawczego, określonego już przez Arystotelesa mianem afairesis - „abstrakcji” oznaczający dosłownie czynność „odrywania”, polega na wydobywaniu przez ludzki rozum form poznawczych z rzeczy, tak że powstała w jego wyniku, istniejąca dalej w intelekcie idea, zawiera w sobie jedynie cechy wspólne dla danej kategorii bytów.

Podczas gdy idea ta, czy też - inaczej mówiąc - pojęcie, pozostaje niematerialne oraz - jeśli tak można powiedzieć - posiada charakter ponadnarodowy w tym sensie, że np. pojęcie samochodu, psa czy domu, takie samo posiadać będą w swoich umysłach przedstawiciele rozmaitych nacji, to już w procesie komunikacji, posługując się językiem, a więc systemem umownych znaków, użyją oni odpowiednio różnych nazw ${ }^{8}$. Języki, którymi posługują się osoby różnych narodowości to zatem - z punktu widzenia semiotyki - nic innego jak alternatywne systemy znaków formalnych, służących do porozumiewania się poszczególnym ludzkim społecznościom?.

słownik filozoficzny, tłum. C. Cieśliński, P. Dziliński, M. Szczubiałka, J. Woleński, Warszawa 1997, s. 460.

7 Zob. Arystoteles, O duszy, 431 b, tłum. P. Siwek, Warszawa 1988.

${ }^{8}$ M.A. Krąpiec posługuje się na oznaczenie pojęcia zapożyczonym od św. Tomasza z Akwinu, łacińskim określeniem verbum mentis - „słowo myśli”. Jest ono - jak zauważa - „racją i uzasadnieniem słów mowy, te ostatnie zaś są znakiem tylko słów myśli”; zob. M.A. Krąpiec, Realizm ludzkiego poznania, Lublin 1995, s. 523-524.

9 Por. Z. Hajduk, Ogólna metodologia nauk, Lublin 2000, s. 23. 


\subsection{POSŁUGIWANIE SIĘ ZNAKAMI JAKO POCHODNA LUDZKIEJ CIELESNOŚCI I RELACYJNOŚCl}

Konieczność posłużenia się znakami pojawia się zatem na etapie, w którym człowiek pragnie podzielić się wynikami swojego poznania $\mathrm{z}$ innymi oraz pozostaje ona $\mathrm{w}$ ścisłym związku $\mathrm{z}$ ludzką cielesnością oraz relacyjnością. Ta ostatnia dotyczyć będzie w szczególności także więzi o charakterze religijnym, jaką człowiek nawiązuje z Bogiem.

Realistyczna filozofia kwestionuje przyjmowany szeroko przez nurty idealistyczne fakt istnienia w ludzkim umyśle jakichkolwiek wrodzonych idei, w oparciu o które miałoby dokonywać się ludzkie poznanie. $\mathrm{W}$ ten sposób poznają jedynie czyste inteligencje, substancje duchowe oddzielone od materii, które w języku religijnym zwykło się nazywać aniołami ${ }^{10}$. Poznanie ludzi jako istot duchowo-cielesnych bierze zawsze swój początek od zmysłów, dzięki którym człowiek nawiązywać może kontakt z otaczającą go rzeczywistością. To one stanowią swego rodzaju bramę, przez którą przejść muszą niezbędne poznawcze dane, by mogły na kolejnym etapie procesu poznawczego zostać poddane intelektualnemu przetwarzaniu. Dotyczy to nie tylko poznania przedmiotów materialnych, ale także przyswajania sobie przez człowieka najbardziej nawet wzniosłych, duchowych treści, czego wyrazem może być słynne stwierdzenie Apostoła Narodów, w myśl którego „wiara rodzi się z tego, co się słyszy” (Rz 10,17).

Stąd też człowiek jako istota duchowo-cielesna, a także $\mathrm{z}$ natury wchodząca $\mathrm{w}$ relacje $\mathrm{z}$ podobnymi sobie istotami, zmuszony jest $\mathrm{w}$ procesie komunikowania swoich myśli sięgać po znaki, które usłyszeć może ludzkie ucho, zobaczyć ludzkie oko, poczuć ludzki dotyk, węch itp. W szczególny sposób dotyczy to także jego relacji do Boga, który w warunkach ziemskich nie jest dostępny człowiekowi w aktach bezpośredniego poznania, ale pojawia się jedynie w osłonach zmysłowych ${ }^{11}$.

10 Aniołowie, jako substancje bezcielesne, nie posiadając zdolności poznania zmysłowego, poznają w sposób, jaki skrajny racjonalizm teoriopoznawczy i idealizm fałszywie przypisują ludziom - przetwarzając wrodzone idee, które w ich intelekcie umieścił Stwórca; zob. T. Dutkiewicz, Filozoficzny spór o przedmiot poznania, a koncepcja poznania duchów czystych w wykładzie angelologii św. Tomasza z Akwinu, „Studia Gdańskie” 39 (2016), s. 157.

11 O tym, że ludzkie poznanie Boga dokonuje się w osłonach zmysłowych, świadczyć mogą poszczególne nazwy, jakimi w różnych językach nazywany bywa Byt Abso- 


\section{ZNAKOWY CHARAKTER LITURGII}

\subsection{LITURGIA, CZYLI „DZIEŁO SPOŁECZNE”}

Już etymologicznie termin „liturgia” oznacza „czyn publiczny”, czy też „działanie dla ludzi”. W starożytnej Grecji liturgią nazywano służbę publiczną. Tak pojmowane "liturgie” były cechą charakterystyczną życia społeczno-politycznego helleńskich demokracji, ale także służbą świątynną w starożytnych religiach misterycznych. Zarówno świeckie, jak i religijne znaczenie terminu "liturgia” spotykamy, co oczywiste, w Septuagincie oraz w Nowym Testamencie. I w takim znaczeniu termin „liturgia”, $\mathrm{z}$ całym jego teologiczno-pastoralnym bogactwem, używany jest w Kościele. Oznacza wyjątkowe, zbawcze działanie ku chwale Boga i dla pożytku duchowego ludzi ${ }^{12}$.

Jak wynika $\mathrm{z}$ analiz prowadzonych $\mathrm{w}$ ramach filozofii religii, choć liturgia - w tym kult, który stanowi jej część integralną - przejawia się w bardzo różnorodnych czynnościach zarówno jednostek, jak i grup wiernych, to jednak podkreślić należy fakt, że - w myśl pierwotnego znaczenia słowa „liturgia”, ale przede wszystkim zgodnie z teologicznym rozumieniem i historiozbawczym sensem liturgii chrześcijańskiej - w isto-

lutny, nawiązujące do jakiegoś aspektu otaczającej człowieka rzeczywistości materialnej: greckie theos zwykło się wywodzić od indoeuropejskiego czasownika dhues - „oddychać”, „żyć”; łacińskie Deus oraz jego odpowiedniki w językach romańskich - Dieu, Dios, Dio pochodzą prawdopodobnie od deivos - „świetlisty”, „promienisty”, „niebiański”; semickie Elohim z kolei od El - „mocny”, Jahwe - od hajah - „być”, „istnieć”; nazwy słowiańskie Bóg, Boh, Bog - pochodzą zaś najprawdopodobniej od staroindyjskiego bhagas oznaczającego „bogactwo”, „pomyślność”, „szczęście”; zob. S. Kowalczyk, Filozofia Boga, Lublin 1997, s. 10. Św. Tomasz, podejmując zagadnienie możliwości bezpośredniego poznania Boga, odwołuje się do arystotelesowskiej zasady, w myśl której „wszelkie nasze poznanie ma początek w zmysłach" i stwierdza, że skoro Bóg jest najbardziej oddalony od zmysłów, to jest przez nas poznawany nie na początku, ale na końcu, nie w sobie samym, ale poprzez dzieło stworzenia, zgodnie z zawartym w I rozdziale Listu do Rzymian stwierdzeniem: „Od stworzenia świata niewidzialne Jego przymioty - wiekuista Jego potęga oraz bóstwo - stają się widzialne dla umysłu poprzez Jego dzieła”; zob. Tomasz z Akwinu, O poznaniu Boga (Super Boetium De Tinitate), I, 3, tłum. P. Lichacz, M. Przanowski, M. Olszewski, Kraków 2005.

12 Zob. S. Marsili, La liturgia, momento storico della salvezza, w: tenże (red.), Anàmnesis, t. 1: La liturgia, momento nella storia dela salvezza, Casale Monferrato 1979, s. 33-45; B. Nadolski, Leksykon liturgii, Poznań 2006, s. 745-748. 
cie swojej posiada charakter społeczny nawet wówczas, gdy poszczególne akty religijne spełnia jednostka.

Święty Tomasz z Akwinu, podejmując w swojej Sumie teologicznej zagadnienie dotyczące konieczności tego, by modlitwa była wyrażana słowami, zauważa, że o ile w przypadku modlitwy wspólnotowej jest to niezbędne, o tyle nawet $\mathrm{w}$ przypadku, gdy modli się pojedyncza osoba, jest to pożyteczne z trzech - jak stwierdza - powodów. Pierwszy z nich Akwinata wywodzi z faktu, że użycie zewnętrznych znaków przyczynia się do pobudzenia wewnętrznej pobożności; drugi wiąże z potrzebą, by cały człowiek - dusza i ciało - oddawał Bogu chwałę wszystkim, co od Niego otrzymał; w trzecim zaś zwraca uwagę na fakt naturalnego oddziaływania duszy na ciało ${ }^{13}$.

\section{2. ŹRÓDŁA I ISTOTA ZNAKOWEGO CHARAKTERU LITURGII}

Znakowy i - patrząc szerzej - ludzki wymiar liturgii, po pierwsze, wiąże się bezpośrednio z unią hipostatyczną dwóch natur w Chrystusie, i wynika z ludzkiej natury Zbawiciela. Po wtóre, liturgia jest anamnezą Misterium Chrystusa dla uświęcenia i zbawienia ludzi. W tym fakcie należy upatrywać podstawowy sens historiozbawczy liturgii, będącej ostatnim, ziemskim etapem historii zbawienia. I wreszcie, liturgia chrześcijańska z racji psychosomatycznej natury człowieka dokonuje się na obecnym etapie dziejów zbawienia pod osłoną widzialnych, ziemskich rzeczywistości ${ }^{14}$.

Aby odkupienie przyniesione przez Chrystusa realizowało się w każdym człowieku poprzez jego osobowe uczestnictwo w Tajemnicy Paschalnej, Misterium Paschalne musi być skutecznie, ale i dostrzegalnie obecne w Kościele. Liturgia Kościoła, ześrodkowana wokół znaków czerpiących swą nadprzyrodzoną skuteczność z historycznych czynów Chry-

13 Zob. Tomasz z Akwinu, Suma teologiczna, II-II, 83, 12.

14 Por. D. Brzeziński, Human Dimension of the Christian Liturgy, „Teologia i Człowiek" 48 (2019) 4, s. 71-89; tenże, Między sacrum i profanum. Granice ludzkiej ingerencji w liturgię, w: D. Kwiatkowski (red.), Obecność sacrum $i$ profanum w liturgii Kościoła. Korzyści i zagrożenia (Colloquia Disputationes, t. 53), Poznań 2020, s. 31-32. 
stusa, jest właśnie tą zbawczą, skuteczną aktualizacją Misterium Paschalnego w czasie ${ }^{15}$.

Bogusław Nadolski określał to jako związek działania mimetycznego z działaniem uobecniającym zbawcze czyny Jezusa. Liturgia łączy nierozdzielnie obydwa te elementy. "Najpierw chodzi o przyjęcie tego, co się dokonało, a więc liturgia jest wspomnieniem, memoria, memoriale, anamnezą czynu Chrystusa [...]. Ten czyn Jezus Chrystus obecny w zgromadzeniu liturgicznym, w mocy Ducha Świętego, uobecnia; Jezus Chrystus jest obecny i jego dzieło - Kapłaństwo Chrystusa - Jesu Christi sacerdotalis muneris exercitatio. Liturgia jest wykonywaniem Chrystusowego kapłaństwa, czyli uobecnieniem Jego czynu zbawczego"16. Liturgia to anàmnesis oraz mimesis Misterium Paschalnego Chrystusa. Chrystus, Bóg-Człowiek, Najwyższy i Wieczny Kapłan, podobnie jak przed dwoma tysiącami lat podczas swojego ziemskiego życia, tak i dzisiaj, za każdym razem, gdy sprawowana jest liturgia, pod osłoną znaków składa sam siebie w Ofierze Bogu Ojcu ${ }^{17}$.

Do widzialnych znaków liturgii przynależą zarówno elementy niezmienne, jak i zmienne. Do rzeczywistości stałych i niepodlegających jakimkolwiek zmianom należą słowa, gesty, symbole i znaki oraz elementy naturalne (jak choćby chleb i wino, które z woli Chrystusa i mocą Jego słów stają się Eucharystią) obecne w liturgii z ustanowienia Bożego.

Obok owego Boskiego (choć w tym wypadku podpadającego pod ludzkie zmysły) pierwiastka, mamy również szereg symboli i znaków, słów i gestów, przedmiotów i elementów naturalnych wprowadzonych do liturgii przez człowieka i podlegających nieuniknionej ewolucji oraz uprawnionej odnowie liturgicznej ${ }^{18}$.

${ }^{15}$ Por. W. Hryniewicz, Liturgia a Misterium Paschalne Chrystusa, w: F. Blachnicki, W. Schenk, R. Zielasko (red.), Wprowadzenie do liturgii, Poznań-Warszawa-Lublin 1967, s. 89.

16 B. Nadolski, Wprowadzenie do liturgii, Kraków 2004, s. 23.

17 Por. Katechizm Kościoła Katolickiego, drugie wyd. poprawione, Poznań 2002, n. 1077-1083; D. Brzeziński, „Chrystus wczoraj i dziś, i na wieki”. Anamnetyczny wymiar roku liturgicznego, Toruń 2015, s. 113-227.

18 Por. A. Läpple, Eucharystia. Ustanowienie, historia, uczestnictwo, tłum. M. Ruta, Kraków 1997, s. 5-35. W tym miejscu nie można przynajmniej nie zasygnalizować istniejącego w języku teologiczno-liturgicznym i liturgiczno-pastoralnym chaosu 


\subsection{JĘZYK LITURGII JAKO SYSTEM ZNAKÓW I JEGO FUNKCJE}

Refleksja filozoficzna prowadzona w stosunku do religii podkreśla semiotyczny (znakowy) charakter liturgii, którą ujmuje jako zbiór znaków, powiązanych z określonym systemem wierzeń oraz religijnych instytucji, za pomocą których to znaków nawiązuje się komunikacja pomiędzy człowiekiem jako podmiotem religijnym a rzeczywistością sakralną ${ }^{19}$. Obok różnorodnych znaków, jakimi posługuje się liturgia, o charakterze optycznym, akustycznym czy motorycznym, szczególne - z punktu wi-

pojęciowego i nadużywania terminu „symbol” w odniesieniu do rzeczywistości liturgicznych, w tym przede wszystkich do znaków liturgicznych. „Termin symbolon - wyjaśnia A. Szyjewski - odnosił się pierwotnie do rozłamanego na dwie części przedmiotu, którego złożenie (symballein - 'dopasowanie', 'składanie') powoduje identyfikację dwóch osób lub ich pełnomocników. We współczesnej humanistyce za symbol zwykło się uważać specyficzny związek, relację znaczącego - formy (signifiant) i znaczonego/znaczenia (signifié), gdzie znaczone może być wieloznaczne, oparte na kojarzeniu, a nie na zasadach logicznych Arystotelesa. Symbol wytwarza pewne pole semantyczne między znaczącym a znaczonym" (A. Szyjewski, Etnologia religii, Kraków 2008, s. 75). Podobnie ujmuje się symbol w Leksykonie religii pod redakcją H. Waldenfelsa: „Symbol, jeśli chodzi o formę, należy zaliczyć do znaków, ponieważ oznacza coś, a zatem nie istnieje wyłącznie dla siebie, lecz wskazuje sobą na coś innego. Ten charakter symbolu, a mianowicie odnoszenia do czegoś innego, łączy płaszczyznę przedstawiania zmysłowego im znaczenia duchowego" (P. Parusel, Symbol, tłum. Z. Wesołowski, w: H. Waldenfels (red.), Leksykon religii. Zjawiska - dzieje - idee, Warszawa 1997, s. 446). Bardzo zbliżone znaczenie nadaje terminowi „symbol” współczesna teologia liturgii. W polskim Leksykonie liturgii B. Nadolskiego czytamy między innymi, iż „symbol jest szczególnym rodzajem znaku. Nie każdy znak jest symbolem, chociaż każdy symbol jest znakiem”. Znakiem może być „słowo, obraz, symbol, gest, postawa, przedmiot, osoba, figura, kolor, ton, litera. Znak pełni rolę zewnętrznej, dostrzegalnej akcji służącej do zakomunikowania czegos’”. „Znak wskazuje na rzeczywistość, symbol jest częścią rzeczywistości oznaczanej”. Rzeczywistość oznaczana przez znaki i symbole jest bardzo szeroka. Hermeneutyka religijna, interpretująca symbole $\mathrm{w}$ religii ( $\mathrm{w}$ tym ich rozumienie i funkcje $\mathrm{w}$ liturgii), przede wszystkim podkreśla rolę symbolu w relacji człowieka i sacrum: symbole są hierofanią (manifestacją) tej relacji i więzi. Każdy znak i każdy symbol posiada - tak jak cała liturgia - cztery podstawowe wymiary: przypominający przeszłość (signum rememorativum); uobecniający oznaczane misterium (signum demonstrativum); zapoczątkowujący pełnię i antycypujący przyszłość (signum eschatologicum - prognosticum); zobowiązujący (wymiar wynikający z trzech pozostałych; signum obligativum); zob. B. Nadolski, Leksykon..., s. 1484-1490; W. Głowa, Znaki i symbole w liturgii, Przemyśl 1995, s. 17-20; K. Porosło, Przez rzeczy widzialne do niewidzialnych - symbol właściwym językiem liturgii, w: tenże (red.), Teologia żyjąca w liturgii, Kraków 2010, s. 86-109.

19 Zob. Z. Zdybicka, Człowiek i religia, s. 199-200. 
dzenia filozoficznego - miejsce przypada językowi, którym posługuje się liturgia ${ }^{20}$.

Język wykorzystywany w liturgii, podobnie jak każdy ludzki język, pozostaje w swojej istocie uporządkowanym systemem znaków. Dopiero wtórnie i akcydentalnie przyjmuje on postać konkretnego języka, jak choćby łacina bądź jakiś język określany mianem narodowego. Język, jakim posługuje się liturgia, wydaje się również spełniać - w różnych proporcjach - najbardziej charakterystyczne funkcje języka, na które wskazuje filozoficzna refleksja prowadzona w ramach semiotyki.

Pierwszą z nich pozostaje funkcja ekspresywna związana $\mathrm{z}$ faktem, że w poszczególnych obrzędach liturgicznych człowiek ujawnia swoje wewnętrzne przeżycia oraz przekonania, wyrażając np. skruchę, wdzięczność, uwielbienie itp. Doskonałym przykładem tej funkcji może być język, z jakim spotykamy się w liturgii godzin, bazującej w zasadniczej swojej części na tekstach zaczerpniętych z biblijnej Księgi Psalmów.

Drugą jest funkcja promotywna języka liturgicznego, związana z motywowaniem uczestników liturgii do przyjęcia określonych postaw, czy też podjęcia określonych działań. Nieprzypadkowo mówi się o wychowaniu poprzez liturgię, czy też o tym, że jest ona podstawową formą katechezy ${ }^{21}$.

Trzecią z funkcji języka stosowanego w liturgii jest funkcja performatywna, z którą mamy do czynienia wszędzie tam, gdzie wypowiadane słowa nie ograniczają się do stwierdzenia określonych faktów, ale stają się ich przyczyną. Przykładem sytuacji, w których język liturgii spełnia funkcję performatywną, pozostają w szczególności stwierdzenia pojawiające się w kontekście sprawowania Sakramentów świętych, takie jak

${ }^{20}$ Chrześcijaństwo od początku interesowało się językiem wiary, o czym świadczą spekulacje na temat logosu, spory terminologiczne o właściwy pojęciowy wyraz prawd wiary, konkurujące ze sobą o właściwą hermeneutykę języka biblijnego szkoły egzegetyczne, aleksandryjska i antiocheńska. Swoje osobne określenie badania z zakresu semiotyki języka religijnego zyskały za sprawą filozofii analitycznej; zob. A. Bronk, Podstawy nauk o religii, Lublin 2003, s. 182.

${ }^{21}$ Zwłaszcza we wczesnym okresie wychowanie religijne dokonuje się przede wszystkim poprzez wdrożenie dziecka w praktykę modlitwy czy liturgii. Podobnie rzecz ma się również z człowiekiem dorosłym, przechodzącym ryt inicjacji; zob. P. Moskal, Religia i prawda, Lublin 2008, s. 191. 
np.: „Ja ciebie chrzczę”, „Ja odpuszczam tobie grzechy”, czy też słowa konsekracji ${ }^{22}$.

Obok wymienionych funkcji języka liturgicznego wspomnieć należy również jego funkcję informatywną, która pozwala uczestniczącym w liturgii przyswajać sobie istotne treści wyznawanej wiary. Wydaje się, że najlepszym przykładem tej funkcji, w jakiej zostaje wykorzystany język stosowany w liturgii, stanowią odmawiane w jej ramach wyznania wiary oraz teksty liturgiczne, zawierające jędrne streszczenia wiary, którą wyznaje Kościół w odniesieniu do poszczególnych kwestii ${ }^{23}$.

\subsection{SAKRAMENTY JAKO „WIDZIALNE ZNAKI NIEWIDZIALNEJ ŁASKI”}

Ktokolwiek zapamiętał z nauki religii, poprzedzającej przyjęcie Komunii Świętej, bądź też sakramentu bierzmowania, definicję tego, czym są sakramenty, kojarzy z pewnością ich określenie jako „znaków widzialnych niewidzialnej łaski”. I chociaż pozostaje - w świetle poczynionych wcześniej filozoficznych uwag, dotyczących natury znaku jako takiego swego rodzaju pleonazmem sformułowanie: „znak widzialny”, to jednak wydaje się ono trafne i usprawiedliwione w aspekcie dydaktycznym. Święty Tomasz z Akwinu cały swój wykład sakramentologii zawarty w Sumie teologicznej rozpoczyna od postawienia pytania, „czy sakrament jest znakiem?"24 Znakowy charakter sakramentów Akwinata wiąże z mądrością Boga, który „zaopatruje każdą istotę zgodnie z jej naturą". Z naturą zaś człowieka - jak wyjaśnia - zgodne jest to, że „przez rzeczy podpadające pod zmysły dochodzi do poznania rzeczy umysłowych"25.

Tomasz zwraca ponadto uwagę na fakt, że tak, jak człowiek składa się z ciała i z duszy, tak też rzeczy podpadającej pod zmysły, winno w spra-

${ }^{22}$ Samo określenie performatywności w odniesieniu do języka wiąże się z pracami Austina i szkoły analitycznej. Można wskazać również, rzecz jasna, pozaliturgiczne, świeckie wykorzystania performatywnej funkcji języka: „mianuję cię porucznikiem”, albo „nadaję ci imię Heweliusz”; zob. M.A. Krąpiec, Filozofia w teologii, Lublin 1999, s. 85.

23 Doskonałym przykładem zwięzłego tekstu liturgicznego, zawierającego obfity ładunek o charakterze dogmatycznym pozostaje prefacja przeznaczona na uroczystość Najświętszej Trójcy.

24 Zob. Tomasz z Akwinu, Suma teologiczna, III, 60, 1.

25 Tamże, III, 60, 4. 
wowanym sakramencie towarzyszyć wypowiadane słowo, które trafiając do duszy budzi w niej odzew wiary ${ }^{26}$. „W sakramentach - jak stwierdza Akwinata - słowa stanowią jakby czynnik istoczący (formę) rzecz zaś postrzegana zmysłem jest jakby tworzywem (materią)"27.

Warto zauważyć, że znakowy charakter posiada zarówno forma-słowo, jak i materia-tworzywo sakramentu. W tekście stanowiącym apologię wiary w realną obecność Zbawiciela w Najświętszym Sakramencie św. Tomasz pisze: „Gdyby zaś ktoś - na podstawie postrzeżeń zmysłowych chciał przeczyć owej przemianie, jako że zmysły nie dostrzegają w sakramencie ołtarza żadnej zmiany, niech weźmie pod uwagę, że wszystko, co Boże, przychodzi do nas pod osłoną rzeczy widzialnych"28.

Skuteczność języka występującego w obrzędach sakramentalnych w wyjątkowej, performatywnej funkcji, św. Tomasz wiąże z faktem, że wypowiadane przez szafarza słowa działają w sakramentach swoją treścią znaczeniową, jaką zawierają. Dopiero w sytuacji, w której zgubiłyby tę treść, znika prawdziwość sakramentu. Charakterystycznym pozostaje fakt, że oparta na filozoficznym fundamencie refleksja sakramentologiczna pozwala Akwinacie uniknąć zarówno nadmiernego laksyzmu w podejściu do wierności sakramentalnym formułom, jak i swego rodzaju magicznego ich traktowania. Kiedy opuści się coś - wyjaśnia Tomasz - co nie stanowi istotnej formy znaczeniowej, nie gubi się tym samym należnej treści znaczeniowej słów oraz - w konsekwencji - nie pozbawia się sakramentu jego ważności, choć sam szafarz popełnia grzech niedbalstwa lub lekceważenia ${ }^{29}$.

${ }^{26}$ Sama woda - jak wyjaśnia Akwinata - może np. oznaczać obmycie ze względu na swoją wilgotność, bądź też napój orzeźwiający - ze względu na swoją świeżość. Dopiero słowna formuła: „Ja ciebie chrzczę” ujawnia, że w kontekście chrztu zostaje ona użyta na oznaczenie oczyszczenia duchowego; zob. Tomasz z Akwinu, Suma teologiczna, III, 60, 6.

27 Tamże, III, 60, 7.

28 Tomasz z Akwinu, Jak uzasadniać wiarę, 8, tłum. J. Salij, w: Tomasz z Akwinu, Dzieła wybrane, Kęty 1999.

${ }_{29}$ Interesujący przykład modyfikacji formuły sakramentalnej przez dodanie słów, które - zdaniem Akwinaty - może nie zmieniać istotnej treści znaczeniowej i nie powodować nieważności sakramentu, dotyczy chrztu udzielonego przy zastosowaniu formuły: „Ja Ciebie chrzczę w Imię Ojca i Syna i Ducha Świętego i w imię błogosławionej Dziewicy", o ile intencją szafarza nie jest uznanie Maryi za równą Trójcy Świętej w akcie chrztu, ale np. przywołanie Jej wstawiennictwa w zachowaniu łaski chrztu; zob. Tomasz z Akwinu, Suma teologiczna, III, 60, 8. 


\section{ZAKOŃCZENIE}

Określenie filozofii mianem „służebnicy teologii” w tym sensie, że dostarcza ona narzędzi służących skutecznej racjonalizacji prawd objawionych, znajduje swoje odniesienie między innymi na terenie teologicznej refleksji dotyczącej natury oraz roli, jaką w liturgii pełnią różnorodne znaki. Znaki liturgiczne, oddziałując na władze zmysłowe człowieka, usposabiają go we właściwy sobie sposób do nawiązywania relacji z Bogiem i oddawania Mu czci, ale przede wszystkim skutecznie „ucieleśniają” hic et nunc zbawcze działanie Boga wobec ludzi. Wszak liturgia to „wypełnianie kapłańskiej funkcji Jezusa Chrystusa”, gdzie „przez znaki dostrzegalne wyraża się i w sposób właściwy dla poszczególnych znaków dokonuje uświęcenie człowieka, a Mistyczne Ciało Jezusa Chrystusa, to jest Głowa ze swymi członkami, sprawuje pełny kult publiczny"30. W tym właśnie sensie C. Vagaggini, jeden z najwybitniejszych twórców współczesnej teologii liturgii, odwołując się w swej refleksji - co należy podkreślić - do nauki Tomaszowej, określał sakramenty, ale i całą liturgię, jako skuteczne znaki uświęcenia i kultu ${ }^{31}$.

Pośród znaków w liturgii na szczególną uwagę zasługuje jej język, którego rozliczne funkcje pozwala wskazać i opisać zastosowanie w refleksji nad liturgią narzędzi wypracowanych na gruncie filozoficznej teorii języka. Wśród powyższych funkcji centralne miejsce znajduje jego funkcja performatywna, której najbardziej doniosłym przykładem wykorzystania pozostają święte sakramenty Kościoła.

${ }^{30}$ Konstytucja o liturgii świętej „Sacrosanctum Concilium”, n. 7, w: Sobór Watykański II, Konstytucje. Dekrety. Deklaracje, tekst polski, nowe tłumaczenie, Poznań 2002, s. 51.

31 Zob. C. Vagaggini, Il senso teologico della liturgia. Saggio di liturgia teologica generale, Roma 1965, s. 17-185. 


\section{BIBLIOGRAFIA}

Arystoteles, O duszy, tłum. P. Siwek, Warszawa 1988.

Blackburn S., Oksfordzki słownik filozoficzny, tłum. C. Cieśliński, P. Dziliński, M. Szczubiałka, J. Woleński, Warszawa 1997.

Bronk A., Podstawy nauk o religii, Lublin 2003.

Brzeziński D., „Chrystus wczoraj i dziś, i na wieki”. Anamnetyczny wymiar roku liturgicznego, Toruń 2015.

Brzeziński D., Human Dimension of the Christian Liturgy, „Teologia i Człowiek” 48 (2019) 4, s. 71-89. DOI: https://doi.org/10.12775/TiCz.2019.043.

Brzeziński D., Między sacrum $i$ profanum. Granice ludzkiej ingerencji w liturgię, w: D. Kwiatkowski (red.), Obecność sacrum i profanum w liturgii Kościoła. Korzyści i zagrożenia (Colloquia Disputationes, t. 53), Poznań 2020, s. 31-49.

Dutkiewicz T., Filozoficzny spór o przedmiot poznania, a koncepcja poznania duchów czystych $w$ wykładzie angelologii św. Tomasza z Akwinu, „Studia Gdańskie” 39 (2016), s. 151-164.

Głowa W., Znaki i symbole w liturgii, Przemyśl 1995.

Hajduk Z., Ogólna metodologia nauk, Lublin 2000.

Hryniewicz W., Liturgia a Misterium Paschalne Chrystusa, w: F. Blachnicki, W. Schenk, R. Zielasko (red.), Wprowadzenie do liturgii, Poznań - Warszawa - Lublin 1967, s. 75-98.

Kamiński S., Metoda i język, Lublin 1994.

Katechizm Kościoła Katolickiego, drugie wyd. poprawione, Poznań 2002.

Konstytucja o liturgii świętej „Sacrosanctum Concilium”, w: Sobór Watykański II, Konstytucje. Dekrety. Deklaracje, tekst polski, nowe tłumaczenie, Poznań 2002, s. 48-78.

Kowalczyk S., Filozofia Boga, Lublin 1997.

Krąpiec M. A., Filozofia w teologii, Lublin 1999.

Krąpiec M. A., Realizm ludzkiego poznania, Lublin 1995.

Läpple A., Eucharystia. Ustanowienie, historia, uczestnictwo, tłum. M. Ruta, Kraków 1997.

Lekka-Kowalik A, Semiotyka, w: A. Maryniarczyk (red.), Powszechna Encyklopedia Filozofii, t. 9, Lublin 2008, s. 19-22.

Marsili S., La liturgia, momento storico della salvezza, w: Marsili S. (red.), Anàmnesis, t. 1: La liturgia, momento nella storia dela salvezza, Casale Monferrato 1979, s. 31-156.

Moskal P., Religia i prawda, Lublin 2008.

Nadolski B., Leksykon liturgii, Poznań 2006.

Nadolski B., Wprowadzenie do liturgii, Kraków 2004.

Parusel P. Symbol, tłum. Z. Wesołowski, w: H. Waldenfels (red.), Leksykon religii. Zjawiska - dzieje - idee, Warszawa 1997, s. 446.

Porosło K., Przez rzeczy widzialne do niewidzialnych - symbol właściwym językiem liturgii, w: K. Porosło (red.), Teologia żyjąca w liturgii, Kraków 2010, s. 86-109.

Stępień A. B., Herbut J., Znak, w: J. Herbut (red)., Leksykon filozofii klasycznej, Lublin 1997, s. 562-564.

Szyjewski A., Etnologia religii, Kraków 2008. 
Tomasz z Akwinu, Jak uzasadniać wiare, tłum. J. Salij, w: Tomasz z Akwinu, Dzieła wybrane, Kęty 1999, s. 325-355.

Tomasz z Akwinu, O poznaniu Boga (Super Boetium De Tinitate), tłum. P. Lichacz, M. Przanowski, M. Olszewski, Kraków 2005.

Tomasz z Akwinu, Suma teologiczna, tłum. F. W. Bednarski, S. Bełch, A. Głażewski, R. Kostecki, S. Piotrowicz, t. 1-35, Londyn 1962-1998.

Vagaggini C., Il senso teologico della liturgia. Saggio di liturgia teologica generale, Roma 1965.

Zdybicka Z., Człowiek i religia, Lublin 1993. 